\title{
Pengaruh Dosis Pupuk Kandang dan Pupuk Urea Terhadap Pertumbuhan Dan Produksi Tanaman Buncis (Phaseolus vulgaris L) di Desa Batuboy Kecamatan Namlea Kabupaten Buru
}

\author{
Said AR. Assagaf $\mathbf{1}^{\bowtie}$ \\ 1 Universitas Iqra Buru, Namlea, Indonesia. \\ Email : saidabdurahmanasegaf@gmail.com

\begin{abstract}
ABSTRAK.
Penelitian ini bertujuan untuk mengetahui Dosis mana yang terbaik dari pemberian Pupuk Kandang dan Urea terhadap hasil Tumbuh Tanaman Buncis (Phaseolus Vulgaris L). Rancangan yang digunakan dalam penelitian ini adalah Rancangan Acak Kelompok (RAK) dengan pola faktorial yang terdiri dari dua faktor, yaitu Pupuk Kandang (K) terdiri dari : K0 = Kontrol (tanpa perlakuan), $\mathrm{K} 1=10$ ton/Ha setara dengan $3 \mathrm{~kg} / \mathrm{bedeng}, \mathrm{K} 2=20$ ton/Ha setara dengan 6 $\mathrm{kg} /$ bedeng dan Pupuk Urea (U) terdiri dari : U0 = Kontrol (tanpan perlakuan), U1 = $200 \mathrm{~kg} / \mathrm{Ha}$ setara dengan $0,06 \mathrm{~g} /$ bedeng , $\mathrm{U} 2=400 \mathrm{~kg} /$ Ha setara dengan $0,12 \mathrm{~g} /$ bedeng dengan ulangi sebanyak $3 \mathrm{kali}$, sehingga terdapat 27 unit percobaan. Setiap percobaan ditentukan 10 tanaman sampel yang diambil secara acak. Hasil penelitian di dapat bahwa pemberian pupuk kandang sapi (organik) 10 ton/Ha setara dengan $3 \mathrm{~kg} /$ bedeng dan 20 ton/Ha setara dengan 6 $\mathrm{kg} /$ bedeng memberikan pengaruh nyata terhadap pertumbuhan dan hasil tanaman buncis, pupuk Urea (anorganik) $200 \mathrm{~kg} / \mathrm{Ha}$ setara dengan 0,06 kg/bedeng dan $400 \mathrm{~kg} / \mathrm{Ha}$ setara dengan $0,12 \mathrm{~kg} /$ bedeng memberikan pengaruh nyata terhadap pertumbuhan dan hasil tanaman buncis dan interaksi antara pemberian pupuk kandang sapi (organik) 10 ton/Ha setara dengan $3 \mathrm{~kg} /$ bedeng dan pupuk Urea (anorganik) $200 \mathrm{~kg} / \mathrm{Ha}$ setara dengan 0,06 $\mathrm{kg} /$ bedeng memberikan pengaruh yang sangat nyata terhadap pertumbuhan dan hasil tanaman buncis.
\end{abstract}

\section{Keywords: Pupuk Urea, Produksi, Bunci, Phaseolus vulgari}

\section{PENDAHULUAN}

Tanaman Buncis (Phaseolus vulgaris L) merupakan tanaman semusim yang berbentuk perdu dan merambat. Panjang rambatan dapat mencapai $3-4 \mathrm{~m}$. buahnya/polongnya pendek, yakni \pm 12 $\mathrm{cm}$, lurus atau benkgok, berwarna hijau mudah. Setiap polong berisi 3 sampai 4 butir biji. Daunnya menyirip tiga dan batangnya bulat kecil memanjang. Biasanya merambat pada ajir yang disediakan untuk pertumbuhannya. Jumlah buah dalam satu tandan berkisar antara 3 sampai 7 buah/polong. Kacang buncis merupakan salah satu sayuran kelompok kacang-kacangan yang digemari masyarakat karena merupakan salah satu sumber protein nabati dan kaya akan vitamin A, B dan C, terutama pada bijinya.( Suwarman S.W, 2005)

Tingginya minat masyarakat Indonesia terhadap sayuran buncis dapat merespon para petani berupaya untuk meningkatkan produksi buncis dari tahun ke tahun. Luas panen tanaman buncis pada tahun 2014 dapat dilihat mencapai $28.632 \mathrm{Ha}$, yang mampu menghasilkan 318.214 ton, yang rata-rata hasil/ Ha mencapai 11,11 ton/Ha. (BPS, 2014). Tingginya produktifitas buncis dalam negeri juga tidak luput dari peran hasil panen buncis di provinsi Maluku setiap tahunnya.

Komoditas pertanian tanaman buncis juga berkembang cukup baik di Pulau Buru. Pada tahun 2011, area tanaman buncis di Pulau Buru seluas 59 Ha, yang hasil produksinya mencapai 178, 29 ton. 2012 (BPS Kabupaten Buru,). Dalam mengusahakan pembudidayaan, petani harus memahami dan mengaplikasikan tekhnik budidaya yang tepat yang telah ditetapkan Departemen Pertanian Republik Indonesia tentang pertanian organik yang tertuang dalam SNI 01-6729-2002. Pertanian organik (Organic Farming) adalah suatu sistem pertanian yang mendorong tanaman dan tanah tetap sehat melalui cara pengelolaan tanah dan tanaman yang disyaratkan dengan pemanfaatan bahan-bahan 
organik atau alamiah sebagai input, dan menghindari penggunaan pupuk buatan dan pestisida kecuali untuk bahan-bahan yang diperkenankan.

Dalam pelaksanaan dan pengembangan sistim pertanian organik, beberapa masalah dan tantangan yang dihadapi oleh para petani, diantaranya produktivitas pertanian organik lebih rendah, sehingga jika tidak ada insentif harga untuk produk organik maka petani tidak akan tertarik berusaha tani pertanian organik. Selain itu kadar hara bahan organik sangat rendah sehingga diperlukan dalam jumlah banyak untuk dapat memenuhi kebutuhan hara tanaman. Karena itu butuh tempat penyimpanan, pengolahan dan ruang yang cukup. Disamping itu membutuhkan biaya angkutan yang besar terutama jika jarak kebun dan rumah sangat jauh. Sehingga sikap petani selama ini terlena oleh cara pertanian yang relatif serba cepat, mudah, kebutuhan relatif lebih sedikit dengan menggunakan tekhnik budidaya anorganik (Sutanto, R., 2006 dalam Lestari AP., 2013).

Selama kurun waktu 20 tahun terakhir ini terjadi kenaikan penggunaan pupuk kimia hampir 5 kali lipat. Hal ini menunjukkan bahwa penggunaan pupuk anorganik sudah sangat tidak efisien dan bahkan kecendrungan yang ada justru terjadi penurunan produktivitas lahan karena menurunnya kandungan bahan organik tanah. Akibatnya saat ini sekitar $60 \%$ kahan pertanian yang tengah 'sakit', akibat penggunaan pupuk anorganik (kimia) yang berlebihan (Kominfo-Newsroom - Departemen Pertanian, 2009).

Pupuk urea adalah pupuk anorganik yang sangat digemari oleh petani Indonesia. Selain karena harganya yang relatif murah, manfaat dan fungsi pupuk urea juga dapat langsung dilihat setelah diaplikasikan pada pertumbuhan tanaman. Manfaat pupuk urea terhadap tumbuh kembang tanaman antara lain:

1. Membuat daun tanaman lebih hijau segar dan banyak mengandung butir hijau daun (chlorophyl) yang mempunyai peranan sangat panting dalam proses fotosintesa.

2. Menambah kandungan protein tanaman.

3. Dapat dipakai untuk semua jenis tanaman baik tanaman pangan, holtikultura, tanaman perkebunan, usaha peternakan dan usaha perikanan.

Sirrapa (2004) dalam Lestari AP., (2013) menjelaskan bahwa penggunaan pupuk anorganik sebaiknya dikombinasikan dengan pupuk organik untuk saling melengkapi. Penggunaan pupuk anorganik yang dikombinasikan dengan pupuk organik akan memberikan pengaruh yang sangat baik bagi pertumbuhan dan hasil tanaman. Hal ini disebabkan karena pupuk organik dapat meningkatkan efisiensi penggunaan pupuk dan daya mengikat air serta mengaktifkan mikro organism tanah. Dengan adanya perbaikan sifat fisik, kimia dan biologi tanah maka kesuburan tanah juga akan meningkat (Sutanto, R., 2006 dalam Lestari, AP., 2013). Dari latar belakang diatas, maka Peneliti mencoba mengkombinasikan antara pupuk organik (pupuk kandang sapi) dengan pupuk anorganik (urea) terhadap pertumbuhan dan hasil tanaman buncis. Dan penelitian diharapkan berguna untuk pengambilan kebijakan disektor pertanian pada komoditas tanaman holtikultura, khususnya tanaman buncis di Kabupaten Buru dan sebagai bahan informasi yang berguna bagi para petani dalam meningkatkan hasil produksi.

\section{METODE PENELITIAN}

Penelitian ini dilaksanakan di Desa Batuboy Kecamatan Namlea Kabupaten Buru, dari bulan Januari - April 2019, dengan menggunakan bahan berupa benih kacang buncis, pupuk kandang sapi, pupuk urea, pestisida dan tiang rayapan dan alat diantaranya sabit, parang, cangkul, handsprayer, timbangan, meteran, tali rafia, ember, papan nama perlakuan dan alat tulis.

Rancangan yang digunakan dalam penelitian ini adalah Rancangan Acak Kelompok (RAK) dengan pola faktorial yang terdiri dari dua factor, dengan faktor I : Pupuk Kandang (K) terdiri dari : $\mathrm{K}_{0}=$ Kontrol (tanpa perlakuan), $\mathrm{K}_{1}=10$ ton $/ \mathrm{Ha}$ setara dengan $3 \mathrm{~kg} /$ bedeng, $\mathrm{K}_{2}=20$ ton $/ \mathrm{Ha}$ setara dengan $6 \mathrm{~kg} /$ bedeng., dan Faktor II : Pupuk Urea (U) terdiri dari : $\mathrm{U}_{0}=$ Kontrol (tanpan perlakuan), $\mathrm{U}_{1}$ $=200 \mathrm{~kg} /$ Ha setara dengan $0,06 \mathrm{~g} /$ bedeng, $U_{2}=400 \mathrm{~kg} /$ Ha setara dengan $0,12 \mathrm{~g} / \mathrm{bedeng}$, dari kedua faktor tersebut terdapat 9 kombinasi perlakuan sebagai berikut:

$\begin{array}{lll}\mathrm{K}_{0} \mathrm{U}_{0} & \mathrm{~K}_{1} \mathrm{U}_{0} & \mathrm{~K}_{2} \mathrm{U}_{0} \\ \mathrm{~K}_{0} \mathrm{U}_{1} & \mathrm{~K}_{1} \mathrm{U}_{1} & \mathrm{~K}_{2} \mathrm{U}_{1} \\ \mathrm{~K}_{0} \mathrm{U}_{2} & \mathrm{~K}_{1} \mathrm{U}_{2} & \mathrm{~K}_{2} \mathrm{U}_{2}\end{array}$

Percobaan ini diulangi sebanyak 3 kali, sehingga terdapat 27 unit percobaan. Setiap percobaan ditentukan 10 tanaman sampel yang diambil secara acak. 
Adapun parameter yang diamati dalam penelitian ini adalah sebagai berikut:

a. Tinggi tanaman (cm), Tinggi tanaman diukur dari permukaan tanah sampai dengan bagian tanaman tertinggi, mulai dari ajir sebagai patokan sampai keujung titik tumbuh batang utama tanaman. Pengamatan mulai dilakukan pada waktu tanaman berumur 1 minggu HST sampai munculnya bunga pertama (sebanyak 3 kali pengamatan) dengan interval waktu pengamatan seminggu sekali, sampai awal waktu berbunga, pada tanaman sampel.

b. Jumlah daun, Pengamatan dilakukan dengan menghitung jumlah daun dari mulai 1 minggu ST sampai awal waktu berbunga, pada tanaman sampel.

c. Jumlah polong (buah) per tanaman,Pengamataan dilakukan dengan menjumlahkan polong dari panen pertama sampai panen terakhir yang telah memenuhi kriteria panen pada setiap tanaman .

d. Panjang polong rata-rata per tanam $(\mathrm{cm})$, Pengamatan terhadap panjang polong rata-rata dilakukan dengan mengukur panjang polong pada setiap tanaman sampel, kemudian dirataratakan. Pengukuran dimulai dari pangakal polong sampai keujung polong melalui belahan tengah polong. Pengukuran dilakukan pada saat sebelum panen.

e. Berat polong per tanaman (kg), Pengamatan terhadap berat polong per tanaman dari setiap tanaman sampel pada setiap kali panen. Angka pengamatan pada setiap kali penimbangan dari masing-masing setiap tanaman sampel disatukan (dijumlahkan) sampai panen terakhir kemudian dirata-ratakan.

Data yanag diperoleh dianalisis dengan menggunakan statistik. Jika terdapa perbedaan yang nyata atau sangat nyata maka dilanjutkan dengan Uji Beda Nilai Jujur (BNJ). (Hanafiah, 2009).

\section{HASIL DAN PEMBAHASAN}

\subsection{Hasil Penelitian}

Data hasil penelitian beserta analisis sidik ragamnya untuk semua parameter secara lengkap dapat dilihat dilampiran, sedangkan rangkuaman hasil analisisnya disajikan pada tabel berikut ini:

Tabel 1. Hasil Analisis Sidik Ragam Parameter-Parameter Pengamatan.

\begin{tabular}{|c|c|c|c|c|c|c|}
\hline \multirow[t]{2}{*}{ No } & \multirow{2}{*}{$\begin{array}{l}\text { Parameter } \\
\text { Pengamatan }\end{array}$} & \multicolumn{5}{|c|}{ Pengaruh Perlakuan } \\
\hline & & Kelompok & Perlakuan & $\begin{array}{c}\text { Pupuk } \\
\text { Kandang }\end{array}$ & $\begin{array}{l}\text { Pupuk } \\
\text { Urea }\end{array}$ & Interaksi \\
\hline \multirow[t]{5}{*}{1} & Tinggi Tanaman & & & & & \\
\hline & Umur 1 MST & $*$ & $* *$ & ** & th & ** \\
\hline & Umur 2 MST & tn & $* *$ & $* *$ & $* *$ & ** \\
\hline & Umur 3 MST & tn & $* *$ & $* *$ & $* *$ & $* *$ \\
\hline & Umur 4 MST & tn & $* *$ & $* *$ & $* *$ & ** \\
\hline \multirow[t]{5}{*}{2} & Jumlah daun & & & & & \\
\hline & Umur 1 MST & tn & ** & $* *$ & $* *$ & tn \\
\hline & Umur 2 MST & tn & $* *$ & $* *$ & * & tn \\
\hline & Umur 3 MST & tn & $* *$ & $* *$ & $* *$ & $* *$ \\
\hline & Umur 4 MST & $* *$ & $* *$ & $* *$ & $* *$ & $* *$ \\
\hline 3 & Panjang polong & $*$ & $*$ & $* *$ & tn & tn \\
\hline 4 & Berat polong & $* *$ & ** & $* *$ & $* *$ & ** \\
\hline 5 & Jumlah polong & tn & ** & ** & ** & ** \\
\hline
\end{tabular}

Table 1 menunjukan bahwa kelompok pada tinggi tanaman dii minggu pertama berpengaruh nyata sedangkan tinggi tanaman dari minggu ke 2 sampai mingguke 4 tidak berpengaruh nyata. 
Sedangkan kelompok untuk jumlah daun dari minggu pertama sampai minggu ke 3 tidak berpengaruh nyata dan dii minggu ke 4 sangat berpengaruh nyata. Kemudian kelompok untuk berat polong berpengaruh sangat nyata sedangkan kelompok untuk jumlah polong berpengaruh tidak nyata.

Pada perlakuan untuk tinggi tanaman, jumlah daun, berat polong, dan jumlah polong berpengaruh sangat nyata sedangkan pada panjang polong berpengaruh nyata. Pemberian pupuk kandang berpengaruh sangat nyata terhadap tinggii tanaman, jumlah daun, panjang polong, berat polong, dan jumlah polong. pada pemberian pupuk urea tinggi tanaman di minggu pertama berpengaruh tidak nyata hal ini disebabkan karena pada minggu pertama belum ada pemberian perlakuan pupuk Urea , pemberian pupuk Urea juga tidak berpengaruh nyata terhadap panjang polong dan berpengaruh sangat nyata terhadap tinggi tanaman, jumlah daun, berat polong, dan jumlah polong.

Pada interaksi untuk tinggi tanaman sangat berpengaruh nyata sedangkan pada jumlah daun di minggu pertama sampai ke 2 tidak berpengaruh nyata dan jumlah daun di minggu ke 3 sampai ke 4 berpengaruh sangat nyata kemudian pada panjang polong tidak berpengaruh nyata sedangkan pada berat polong dan jumlah polong berpengaruh sangat nyata

\section{a. Tinggi tanaman buncis umur 1 MST}

Hasil uji BNJ parameter tinggi tanaman Buncis umur 1 MST disajikan pada tabel berikut ini :

Tabel 2. Hasil Analisis Sidik Ragam Parameter tinggi tanaman Buncis 1 MST .

\begin{tabular}{ccccc}
\hline Perlakuan & $\mathbf{U}_{\mathbf{0}}$ & $\mathbf{U}_{\mathbf{1}}$ & $\mathbf{U}_{\mathbf{2}}$ & Rataan \\
\hline $\mathbf{K}_{\mathbf{0}}$ & $6,66 \mathrm{a}$ & $6,7 \mathrm{a}$ & $6,66 \mathrm{a}$ & $6,68 \mathrm{a}$ \\
$\mathbf{K}_{\mathbf{1}}$ & $11,76 \mathrm{~b}$ & $12,33 \mathrm{~b}$ & $12,1 \mathrm{~b}$ & $12,07 \mathrm{~b}$ \\
$\mathbf{K}_{\mathbf{2}}$ & $12,8 \mathrm{~b}$ & $12,73 \mathrm{~b}$ & $12,83 \mathrm{~b}$ & $12,78 \mathrm{c}$ \\
\hline Rataan & $10,40 \mathrm{a}$ & $10,58 \mathrm{a}$ & $10,53 \mathrm{a}$ & \\
\hline BNJ 0,05 & 0,5 & & & \\
\hline Keterangan: Angka-angka yang diikuti & oleh huruf yang sama tidak berbeda nyata \\
pada uji taraf 5\% &
\end{tabular}

Hasil uji BNJ $(0,05)$ pada tabel 2 menunjukan bahwa perlakuan pupuk kandang $\left(\mathrm{K}_{2}\right)$ dengan dosis pupuk $6 \mathrm{~kg} /$ bedeng memperlihatkan tinggi tanaman yang terbaik diminggu pertama yaitu $12,78 \mathrm{~cm}$, berbeda nyata dengan tanpa perlakuan $\left(\mathrm{K}_{0}\right)$ yaitu $6,68 \mathrm{~cm}$, dan perlakuan $\left(\mathrm{K}_{1}\right)$ yaitu 12,07 $\mathrm{cm}$.

Pada tabel menunjukan bahwa untuk pupuk urea dan kombinasi tidak berpengaruh nyata hal ini disebabkan karena pada minggu pertama belum ada perlakuan pupuk urea.

\section{b. Tinggi tanaman buncis umur 2 MST}

Hasil uji BNJ parameter tinggi tanaman Buncis umur 2 MST disajikan pada tabel berikut :

Tabel 3. Hasil analisis sidik ragam parameter tinggi tanaman Buncis umur 2 MST.

\begin{tabular}{ccccc}
\hline Perlakuan & $\mathbf{U}_{\mathbf{0}}$ & $\mathbf{U}_{\mathbf{1}}$ & $\mathbf{U}_{\mathbf{2}}$ & Rataan \\
\hline Ko & $18,57 \mathrm{~b}$ & $6,60 \mathrm{a}$ & $33,67 \mathrm{e}$ & $26,28 \mathrm{a}$ \\
$\mathbf{K}_{\mathbf{1}}$ & $21,53 \mathrm{c}$ & $47,17 \mathrm{~h}$ & $41,23 \mathrm{f}$ & $36,64 \mathrm{c}$ \\
$\mathbf{K}_{\mathbf{2}}$ & $21,77 \mathrm{c}$ & $27,33 \mathrm{~d}$ & $43,97 \mathrm{~g}$ & $31,02 \mathrm{~b}$ \\
\hline Rataan & $20,62 \mathrm{a}$ & $27,03 \mathrm{~b}$ & $39,62 \mathrm{c}$ & \\
\hline BNJ 0,05 & 1,5 & & & \\
\hline Keterangan: Angka-angka yang diikuti oleh huruf yang sama tidak berbeda nyata \\
pada uji taraf 5\%
\end{tabular}

Hasil uji BNJ $(0,05)$ pada tabel 3 menunjukan bahwa perlakuan pupuk kandang $\left(\mathrm{K}_{1}\right)$ dengan dosis pupuk $3 \mathrm{~kg} /$ bedeng memperlihatkan tinggi tanaman yang terbaik diminggu kedua yaitu 36,64 $\mathrm{cm}$, berbeda nyata dengan tanpa perlakuan $\left(\mathrm{K}_{0}\right)$ dan perlakuan $\left(\mathrm{K}_{2}\right)$.

Penggunaan pupuk Urea $\left(\mathrm{U}_{2}\right)$ dengan dosis pupuk $120 \mathrm{gr} /$ bedeng memperlihatkan tinggi tanaman yang terbaik yaitu $39,62 \mathrm{~cm}$, berbeda nyata dengan perlakuan lainnya. Pada kombinasi perlakuan $\mathrm{K}_{1} \mathrm{U}_{1}$ memperlihatkan tinggi tanaman yang terbaik yaitu $47,17 \mathrm{~cm}$, berbeda nyata dengan perlakuan lainnya. 


\section{c. Tinggi tanaman buncis umur 3 MST}

Hasil uji BNJ parameter tinggi tanaman Buncis umur 3 MST disajikan pada tabel berikut:

Tabel 4. Hasil analisis sidik ragam parameter tinggi tanaman Buncis umur 3 MST.

\begin{tabular}{ccccc}
\hline Perlakuan & $\mathbf{U}_{\mathbf{0}}$ & $\mathbf{U}_{\mathbf{1}}$ & $\mathbf{U}_{\mathbf{2}}$ & Rataan \\
\hline $\mathbf{K}_{\mathbf{0}}$ & $48,67 \mathrm{a}$ & $94,5 \mathrm{~b}$ & $88 \mathrm{~b}$ & $77,06 \mathrm{a}$ \\
$\mathbf{K}_{\mathbf{1}}$ & $82,67 \mathrm{~b}$ & $119,17 \mathrm{~b}$ & $100,17 \mathrm{~b}$ & $100,67 \mathrm{a}$ \\
$\mathbf{K}_{\mathbf{2}}$ & $98,5 \mathrm{~b}$ & $84,83 \mathrm{~b}$ & $106,17 \mathrm{~b}$ & $96,5 \mathrm{a}$ \\
\hline Rataan & $76,61 \mathrm{a}$ & $99,5 \mathrm{~b}$ & $98,11 \mathrm{~b}$ & \\
\hline BNJ 0,05 & 20,12 & & & \\
\multicolumn{4}{r}{ Keterangan: Angka-angka yang diikuti oleh hurufyang sama tidak berbeda nyata } \\
pada uji taraf 5\%
\end{tabular}

Hasil uji BNJ $(0,05)$ pada tabel 4 menunjukan bahwa perlakuan pupuk kandang $\left(\mathrm{K}_{1}\right)$ dengan dosis pupuk $3 \mathrm{~kg} /$ bedeng memperlihatkan tinggi tanaman yang terbaik diminggu ketiga yaitu 100,67 $\mathrm{cm}$, berbeda nyata dengan tanpa perlakuan $\left(\mathrm{K}_{0}\right)$ dan perlakuan $\left(\mathrm{K}_{2}\right)$.

Penggunaan pupuk Urea $\left(\mathrm{U}_{1}\right)$ dengan dosis pupuk $60 \mathrm{gr} /$ bedeng memperlihatkan tinggi tanaman yang terbaik yaitu $99,5 \mathrm{~cm}$, berbeda nyata dengan perlakuan $\left(\mathrm{U}_{0}\right)$.sedangkan dengan perlakuan $\left(U_{2}\right)$ tidak berbeda nyata. Pada kombinasi perlakuan $\mathrm{K}_{1} \mathrm{U}_{1}$ memperlihatkan tinggi tanaman yang terbaik yaitu $119,17 \mathrm{~cm}$, berbeda nyata dengan tanpa perlakuan $\left(\mathrm{K}_{0}\right)$ sedangkan pada perlakuan lainnya tidak berbeda nyata

\section{d. Tinggi tanaman buncis umur 4 MST}

Hasil uji BNJ parameter tinggi tanaman Buncis umur 4 MST disajikan pada tabel berikut :

Tabel 5. Hasil analisis sidik ragam parameter tinggi tanaman Buncis umur 4 MST.

\begin{tabular}{ccccc}
\hline Perlakuan & $\mathbf{U}_{\mathbf{0}}$ & $\mathbf{U}_{\mathbf{1}}$ & $\mathbf{U}_{\mathbf{2}}$ & Rataan \\
\hline $\mathbf{K}_{\mathbf{0}}$ & $111,67 \mathrm{a}$ & $171,67 \mathrm{a}$ & $166,5 \mathrm{a}$ & $149,94 \mathrm{a}$ \\
$\mathbf{K}_{\mathbf{1}}$ & $169,33 \mathrm{a}$ & $212,33 \mathrm{~b}$ & $170 \mathrm{a}$ & $183,89 \mathrm{~b}$ \\
$\mathbf{K}_{\mathbf{2}}$ & $162 \mathrm{a}$ & $172 \mathrm{a}$ & $211 \mathrm{~b}$ & $182,01 \mathrm{~b}$ \\
\hline Rataan & $147,67 \mathrm{a}$ & $185,33 \mathrm{c}$ & $182,5 \mathrm{~b}$ \\
\hline BNJ 0,05 & 6,33 & & \\
\hline \multicolumn{5}{r}{ Keterangan: Angka-angka yang diikuti oleh huruf yang sama tidak berbeda } \\
nyata pada uji taraf 5\%
\end{tabular}

Hasil uji BNJ $(0,05)$ pada tabel 5 menunjukan bahwa perlakuan pupuk kandang $\left(\mathrm{K}_{1}\right)$ dengan dosis pupuk $3 \mathrm{~kg} /$ bedeng memperlihatkan tinggi tanaman yang terbaik diminggu keempat yaitu $183,89 \mathrm{~cm}$, berbeda nyata dengan tanpa perlakuan $\left(\mathrm{K}_{0}\right)$, sedangkan dengan perlakuan $\left(\mathrm{K}_{2}\right)$ tidak berbeda nyata.

Penggunaan pupuk Urea $\left(U_{1}\right)$ dengan dosis pupuk $60 \mathrm{gr} /$ bedeng memperlihatkan tinggi tanaman yang terbaik yaitu $185,33 \mathrm{~cm}$, berbeda nyata dengan perlakuan $\left(\mathrm{U}_{0}\right)$ dengan perlakuan $\left(\mathrm{U}_{2}\right)$. Pada kombinasi perlakuan $\left(\mathrm{K}_{1} \mathrm{U}_{1}\right)$ memperlihatkan tinggi tanaman yang terbaik yaitu $212,33 \mathrm{~cm}$, tidak berbeda nyata dengan perlakuan $\left(\mathrm{K}_{2} \mathrm{U}_{2}\right)$ sedangkan dengan perlakuan lainnya berbeda nyata.

\section{f. Jumlah daun 1 MST} berikut :

Hasil uji BNJ parameter jumlah daun tanaman Buncis umur 1 MST disajikan pada tabel

Tabel 6. Hasil analisis sidik ragam parameter jumlah daun tanaman Buncis umur 1 MST.

\begin{tabular}{ccccc}
\hline Perlakuan & $\mathbf{U}_{\mathbf{0}}$ & $\mathbf{U}_{\mathbf{1}}$ & $\mathbf{U}_{\mathbf{2}}$ & Rataan \\
\hline $\mathbf{K}_{\mathbf{0}}$ & $2 \mathrm{a}$ & $2 \mathrm{a}$ & $2 \mathrm{a}$ & $2 \mathrm{a}$ \\
$\mathbf{K}_{\mathbf{1}}$ & $2,8 \mathrm{a}$ & $2,8 \mathrm{a}$ & $2,8 \mathrm{a}$ & $2,8 \mathrm{a}$ \\
$\mathbf{K}_{\mathbf{2}}$ & $2,87 \mathrm{a}$ & $2,9 \mathrm{a}$ & $2,9 \mathrm{a}$ & $2,89 \mathrm{a}$ \\
\hline Rataan & $2,56 \mathrm{a}$ & $2,57 \mathrm{a}$ & $2,57 \mathrm{a}$ & \\
\hline BNJ 0,05 & 0,15 & & & \\
\hline Keterangan: Angka-angka yang diikuti oleh huruf yang sama tidak berbeda nyata \\
pada uji taraf 5\%
\end{tabular}


Hasil uji BNJ $(0,05)$ pada table 6 menunjukan bahwa perlakuan pupuk kandang $\left(\mathrm{K}_{2}\right)$ dengan dosis pupuk $6 \mathrm{~kg} /$ bedeng memperlihatkan jumlah daun terbaik diminggu pertama yaitu 2,89 daun, berbeda nyata dengan tanpa perlakuan $\left(\mathrm{K}_{0}\right)$ dan nyata dengan perlakuan $\left(\mathrm{K}_{2}\right)$.

Penggunaan pupuk Urea $\left(\mathrm{U}_{1}\right)$ dan $\left(\mathrm{U}_{2}\right)$ memperlihatkan jumlah daun yang terbaik yaitu 2,57 daun dan tidak berbeda nyata dengan tanpa perlakuan $\left(U_{0}\right)$ yaitu 2,56 daun. Pada kombinasi semua perlakuan memperlihatkan jumlah daun yang yang hampir sama atau tidak berbeda nyata.

\section{g. Jumlah daun 2 MST} berikut :

Hasil uji BNJ parameter jumlah daun tanaman Buncis umur 2 MST disajikan pada tabel

Tabel 7. Hasil analisis sidik ragam parameter jumlah daun tanaman Buncis umur 2 MST.

\begin{tabular}{ccccc}
\hline Perlakuan & $\mathbf{U}_{\mathbf{0}}$ & $\mathbf{U}_{\mathbf{1}}$ & $\mathbf{U}_{\mathbf{2}}$ & Rataan \\
\hline $\mathbf{K}_{\mathbf{0}}$ & $6,63 \mathrm{a}$ & $9,97 \mathrm{~b}$ & $11,1 \mathrm{~b}$ & $9,23 \mathrm{a}$ \\
$\mathbf{K}_{\mathbf{1}}$ & $7,73 \mathrm{a}$ & $14,17 \mathrm{c}$ & $12,0 \mathrm{~b}$ & $11,3 \mathrm{~b}$ \\
$\mathbf{K}_{\mathbf{2}}$ & $11,4 \mathrm{~b}$ & $11,2 \mathrm{~b}$ & $13,27 \mathrm{c}$ & $11,96 \mathrm{~b}$ \\
\hline Rataan & $8,59 \mathrm{a}$ & $11,78 \mathrm{~b}$ & $12,12 \mathrm{~b}$ \\
\hline BNJ 0,05 & 1,1 & \\
\multicolumn{5}{l}{ Keterangan: Angka-angka yang diikuti oleh huruf yang sama tidak berbeda nyata } \\
pada uji taraf 5\%
\end{tabular}

Hasil uji BNJ $(0,05)$ pada tabel 4.7 menunjukan bahwa perlakuan pupuk kandang $\left(\mathrm{K}_{2}\right)$ dengan dosis pupuk $6 \mathrm{~kg} /$ bedeng memperlihatkan jumlah daun yang terbanyak diminggu kedua yaitu 11,96 daun, berbeda nyata dengan tanpa perlakuan $\left(\mathrm{K}_{0}\right)$ dan tidak berbeda nyata dengan perlakuan $\left(\mathrm{K}_{1}\right)$.

Penggunaan pupuk Urea $\left(\mathrm{U}_{2}\right)$ dengan dosis pupuk $120 \mathrm{gr} /$ bedeng memperlihatkan jumlah daun yang terbanyak yaitu 12,12 daun, berbeda nyata dengan tanpa perlakuan $\left(\mathrm{U}_{0}\right)$ dan tidak berbeda nyata dengan perlakuan $\mathrm{U}_{2}$. Pada kombinasi perlakuan $\mathrm{K}_{1} \mathrm{U}_{1}$ memperlihatkan jumlah daun yang terbanyak yaitu 14,17 daun, berbeda nyata dengan perlakuan $\left(\mathrm{K}_{2} \mathrm{U}_{1}\right)$ dan perlakuan $\left(\mathrm{K}_{1} \mathrm{U}_{2}\right)$ tudak berbeda nyata dengan perlakuan $\left(\mathrm{K}_{2} \mathrm{U}_{2}\right)$.

\section{h. Jumlah daun 3 MST} berikut :

Hasil uji BNJ parameter jumlah daun tanaman Buncis umur 3 MST disajikan pada tabel

Tabel 8. Hasil analisis sidik ragam parameter jumlah daun tanaman Buncis umur 3 MST.

\begin{tabular}{ccccc}
\hline Perlakuan & $\mathbf{U}_{\mathbf{0}}$ & $\mathbf{U}_{\mathbf{1}}$ & $\mathbf{U}_{\mathbf{2}}$ & Rataan \\
\hline $\mathbf{K}_{\mathbf{0}}$ & $21,03 \mathrm{a}$ & $36,17 \mathrm{~b}$ & $43,67 \mathrm{~b}$ & $33,62 \mathrm{a}$ \\
$\mathbf{K}_{\mathbf{1}}$ & $53,13 \mathrm{~b}$ & $69,2 \mathrm{~b}$ & $42,5 \mathrm{~b}$ & $54,94 \mathrm{~b}$ \\
$\mathbf{K}_{\mathbf{2}}$ & $43,57 \mathrm{~b}$ & $51,2 \mathrm{~b}$ & $63,83 \mathrm{~b}$ & $52,87 \mathrm{~b}$ \\
\hline Rataan & $39,24 \mathrm{a}$ & $52,19 \mathrm{a}$ & $50 \mathrm{a}$ & \\
\hline BNJ 0,05 & 14,93 & & \\
\hline Keterangan: & Angka-angka yang diikuti oleh & huruf yang sama & tidak berbeda \\
& nyata pada uji taraf 5\%
\end{tabular}

Hasil uji BNJ $(0,05)$ pada tabel 4.8 menunjukan bahwa perlakuan pupuk kandang $\left(\mathrm{K}_{1}\right)$ dengan dosis pupuk $3 \mathrm{~kg}$ /bedeng memperlihatkan jumlah daun yang terbanyak diminggu ketiga yaitu 54,94 daun, tidak berbeda nyata dengan perlakuan $\left(\mathrm{K}_{2}\right)$ yaitu 52,87 daun,sedangkan tanpa perlakuan $\left(\mathrm{K}_{0}\right)$ berbeda nyata yaitu 33,62 daun .

Penggunaan pupuk Urea $\left(U_{1}\right)$ dengan dosis pupuk $60 \mathrm{gr} /$ bedeng memperlihatkan jumlah daun yang terbanyak yaitu 52,19 daun, berbeda nyata dengan perlakuan $\left(U_{2}\right)$ dan tanpa perlakuan $\left(U_{0}\right)$. Pada kombinasi perlakuan $\mathrm{K}_{1} \mathrm{U}_{1}$ memperlihatkan jumlah daun yang terbanyak yaitu 69,2 berbeda nyata dengan perlakuan $\left(\mathrm{K}_{1} \mathrm{U}_{2}\right)$ dan perlakuan $\left(\mathrm{K}_{2} \mathrm{U}_{1}\right)$ tidak berbeda nyata dengan perlakuan $\left(\mathrm{K}_{2} \mathrm{U}_{2}\right)$.

\section{i. Jumlah daun 4 MST} berikut :

Hasil uji BNJ parameter jumlah daun tanaman Buncis umur 4 MST disajikan pada tabel 
Tabel 9. Hasil analisis sidik ragam parameter jumlah daun tanaman Buncis umur 4 MST penelitian Pengaruh Dosisi Pupuk kandang dan pupuk Urea terhadap pertumbuhan dan Produksi tanaman Buncis (Phaseolus vulgaris $\mathrm{L}$ ).

\begin{tabular}{ccccc}
\hline Perlakuan & $\mathbf{U}_{\mathbf{0}}$ & $\mathbf{U}_{\mathbf{1}}$ & $\mathbf{U}_{\mathbf{2}}$ & Rataan \\
\hline $\mathbf{K}_{\mathbf{0}}$ & $57,93 \mathrm{a}$ & $116,77 \mathrm{~b}$ & $119,13 \mathrm{~b}$ & $97,94 \mathrm{a}$ \\
$\mathbf{K}_{\mathbf{1}}$ & $118,63 \mathrm{~b}$ & $168 \mathrm{c}$ & $117,97 \mathrm{~b}$ & $134,87 \mathrm{~b}$ \\
$\mathbf{K}_{\mathbf{2}}$ & $117,60 \mathrm{~b}$ & $118,80 \mathrm{~b}$ & $165 \mathrm{c}$ & $133,8 \mathrm{~b}$ \\
\hline Rataan & $98,05 \mathrm{a}$ & $134,52 \mathrm{~b}$ & $134,03 \mathrm{~b}$ & \\
\hline BNJ 0,05 & 1,81 & & & \\
\hline Keterangan: Angka-angka yang diikuti oleh huruf yang sama tidak berbeda nyata \\
pada uji taraf 5\%
\end{tabular}

Hasil uji BNJ $(0,05)$ pada table 9 menunjukan bahwa perlakuan pupuk kandang $\left(\mathrm{K}_{1}\right)$ dengan dosis pupuk $3 \mathrm{~kg} /$ bedeng memperlihatkan jumlah daun yang terbanyak diminggu keempat yaitu 134,87 daun, tidak berbeda nyata dengan perlakuan $\left(K_{2}\right)$ yaitu 133,8 daun,sedangkan tanpa perlakuan $\left(\mathrm{K}_{0}\right)$ berbeda nyata yaitu 97,94 daun .

Penggunaan pupuk Urea $\left(\mathrm{U}_{1}\right)$ dengan dosis pupuk 60 gr/bedeng memperlihatkan jumlah daun yang terbanyak yaitu 134,52 daun, tidak berbeda nyata dengan perlakuan $\left(U_{2}\right)$ dan berbeda nyata dengan tanpa perlakuan $\left(\mathrm{U}_{0}\right)$. Pada kombinasi perlakuan $\mathrm{K}_{2} \mathrm{U}_{1}$ memperlihatkan jumlah daun yang terbanyak yaitu 118,80 berbeda nyata dengan perlakuan $\left(\mathrm{K}_{2} \mathrm{U}_{2}\right)$ dan perlakuan $\left(\mathrm{K}_{1} \mathrm{U}_{1}\right)$ tidak berbeda nyata dengan perlakuan $\left(\mathrm{K}_{1} \mathrm{U}_{2}\right)$.

\section{j. Berat polong}

Hasil uji BNJ parameter berat polong tanaman Buncis disajikan pada tabel berikut :

Tabel 3.10. Hasil analisis sidik ragam parameter berat polong tanaman Buncis .

\begin{tabular}{ccccc}
\hline Perlakuan & $\mathbf{U}_{\mathbf{0}}$ & $\mathbf{U}_{\mathbf{1}}$ & $\mathbf{U}_{\mathbf{2}}$ & Rataan \\
\hline $\mathbf{K}_{\mathbf{0}}$ & $606,67 \mathrm{a}$ & $686,67 \mathrm{a}$ & $748,33 \mathrm{a}$ & $680,56 \mathrm{a}$ \\
$\mathbf{K}_{\mathbf{1}}$ & $661 \mathrm{a}$ & $1093,33 \mathrm{~b}$ & $1116,67 \mathrm{~b}$ & $957 \mathrm{~b}$ \\
$\mathbf{K}_{\mathbf{2}}$ & $833,33 \mathrm{a}$ & $1108,33 \mathrm{~b}$ & $1162,67 \mathrm{~b}$ & $1034,78 \mathrm{~b}$ \\
\hline Rataan & $700,33 \mathrm{a}$ & $962,78 \mathrm{~b}$ & $1009,22 \mathrm{~b}$ & \\
\hline BNJ 0,05 & 149,64 & \multicolumn{4}{|}{} \\
\hline Keterangan: Angka-angka yang diikuti oleh hurufyang sama tidak berbeda nyata pada uji taraf 5\%
\end{tabular}

Hasil uji BNJ $(0,05)$ pada tabel 10. menunjukan bahwa perlakuan pupuk kandang $\left(\mathrm{K}_{2}\right)$ dengan dosis pupuk $6 \mathrm{~kg} /$ bedeng memperlihatkan berat polong yang terbaik yaitu 1034,78 gr berbeda nyata dengan tanpa perlakuan $\left(\mathrm{K}_{0}\right)$ yaitu 680,56 gr dan perlakuan $\left(\mathrm{K}_{1}\right)$ yaitu $957 \mathrm{gr}$

Penggunaan pupuk Urea $\left(\mathrm{U}_{2}\right)$ dengan dosis pupuk $120 \mathrm{gr} /$ bedeng memperlihatkan berat polong yang terbaik yaitu 1009,22 gr tidak berbeda nyata dengan perlakuan $\left(\mathrm{U}_{1}\right)$ dan berbeda nyata dengan tanpa perlakuan $\left(\mathrm{U}_{0}\right)$. Pada kombinasi perlakuan $\left(\mathrm{K}_{2} \mathrm{U}_{2}\right)$ memperlihatkan berat polong yang terbanyak yaitu 1162,67 gr berbeda nyata dengan perlakuan lainnya.

\section{k. Panjang polong (cm)}

Hasil uji BNJ parameter panjang polong tanaman buncis disajikan pada tabel berikut :

Tabel 11. Hasil analisis sidik ragam parameter panjang polong tanaman Buncis

\begin{tabular}{ccccc}
\hline Perlakuan & $\mathbf{U}_{\mathbf{0}}$ & $\mathbf{U}_{\mathbf{1}}$ & $\mathbf{U}_{\mathbf{2}}$ & Rataan \\
\hline $\mathbf{K}_{\mathbf{0}}$ & $7,9 \mathrm{a}$ & $8,63 \mathrm{a}$ & $9 \mathrm{a}$ & $8,51 \mathrm{a}$ \\
$\mathbf{K}_{\mathbf{1}}$ & $8,77 \mathrm{a}$ & $9,77 \mathrm{a}$ & $9,73 \mathrm{a}$ & $9,42 \mathrm{a}$ \\
$\mathbf{K}_{\mathbf{2}}$ & $10,03 \mathrm{a}$ & $11,77 \mathrm{a}$ & $10,27 \mathrm{a}$ & $10,69 \mathrm{a}$ \\
\hline Rataan & $8,9 \mathrm{a}$ & $10,05 \mathrm{a}$ & $9,66 \mathrm{a}$ & \\
\hline BNJ 0,05 & 3,06 & &
\end{tabular}

Hasil uji BNJ $(0,05)$ pada table 11. menunjukan bahwa perlakuan pupuk kandang $\left(\mathrm{K}_{2}\right)$ dengan dosis pupuk $6 \mathrm{~kg} /$ bedeng memperlihatkan panjang polong yang terbaik yaitu 10,69 $\mathrm{cm}$, berbeda nyata dengan tanpa perlakuan $\left(K_{0}\right)$ yaitu $8,51 \mathrm{~cm}$ dan perlakuan $\left(K_{1}\right)$ yaitu $9,42 \mathrm{~cm}$.

Penggunaan pupuk Urea $\left(\mathrm{U}_{1}\right)$ dengan dosis pupuk $60 \mathrm{gr} /$ bedeng memperlihatkan panjang polong yang terbaik yaitu, $10,05 \mathrm{~cm}$ tidak berbeda nyata dengan perlakuan $\left(U_{1}\right)$ dan tanpa perlakuan 
$\left(\mathrm{U}_{0}\right)$. Pada kombinasi perlakuan $\left(\mathrm{K}_{2} \mathrm{U}_{1}\right)$ memperlihatkan panjang polong yang terbaik yaitu $11,77 \mathrm{~cm}$ berbeda nyata dengan perlakuan $\left(\mathrm{K}_{1} \mathrm{U}_{1}\right)$ dan perlakuan $\left(\mathrm{K}_{1} \mathrm{U}_{2}\right)$ dan tidak berbeda nyata dengan perlakuan $\left(\mathrm{K}_{2} \mathrm{U}_{2}\right)$.

\section{l. Jumlah polong}

Hasil uji BNJ parameter berat polong tanaman Buncis disajikan pada tabel berikut :

Tabel 12. Hasil analisis sidik ragam parameter jumlah polong tanaman Buncis

\begin{tabular}{ccccc}
\hline Perlakuan & $\mathbf{U}_{\mathbf{0}}$ & $\mathbf{U}_{\mathbf{1}}$ & $\mathbf{U}_{\mathbf{2}}$ & Rataan \\
\hline $\mathbf{K}_{\mathbf{0}}$ & $78,33 \mathrm{a}$ & $95 \mathrm{~b}$ & $111,67 \mathrm{~b}$ & $95 \mathrm{a}$ \\
$\mathbf{K}_{\mathbf{1}}$ & $96,67 \mathrm{~b}$ & $145 \mathrm{~b}$ & $151,67 \mathrm{~b}$ & $131,11 \mathrm{~b}$ \\
$\mathbf{K}_{\mathbf{2}}$ & $108,33 \mathrm{~b}$ & $131,67 \mathrm{~b}$ & $155 \mathrm{~b}$ & $131,67 \mathrm{~b}$ \\
\hline Rataan & $94,44 \mathrm{a}$ & $123,89 \mathrm{~b}$ & $139,44 \mathrm{~b}$ & \\
\hline BNJ 0,05 & 24,49 & & & \\
\hline
\end{tabular}

Keterangan: Angka-angka yang diikuti oleh huruf yang sama tidak berbeda nyata pada uji taraf $5 \%$

Hasil uji BNJ $(0,05)$ pada tabel 4.12. Menunjukan bahwa perlakuan pupuk kandang $\left(\mathrm{K}_{2}\right)$ dengan dosis pupuk $6 \mathrm{~kg} /$ bedeng memperlihatkan jumlah polong yang terbaik yaitu 131,67 polong berbeda nyata dengan tanpa perlakuan $\left(\mathrm{K}_{0}\right)$ yaitu 95 polong dan tidak berbeda nyata dengan perlakuan $\left(\mathrm{K}_{1}\right)$ yaitu 131,11 polong

Penggunaan pupuk Urea $\left(\mathrm{U}_{2}\right)$ dengan dosis pupuk $120 \mathrm{gr} /$ bedeng memperlihatkan berat polong yang terbaik yaitu 139,44 berbeda nyata dengan perlakuan $\left(\mathrm{U}_{1}\right)$ dan tanpa perlakuan $\left(\mathrm{U}_{0}\right)$. Pada kombinasi perlakuan $\left(\mathrm{K}_{1} \mathrm{U}_{2}\right)$ memperlihatkan berat polong yang terbaik yaitu 151,67 berbeda nyata dengan perlakuan $\left(\mathrm{K}_{1} \mathrm{U}_{1}\right),\left(\mathrm{K}_{2} \mathrm{U}_{2}\right)$ dan $\left(\mathrm{K}_{2} \mathrm{U}_{1}\right)$.

\subsection{Pembahasan}

Hasil penelitian didapatkan bahwa pemberian pupuk kandang kotoran sapi memberikan pengaruh yang sangat nyata terhadap pertumbuhan dan hasil tanaman buncis, baik pada tinggi tanaman , jumlah daun, jumlah buah (polong), panjang polong dan berat polong. Pemberian pupuk kandang sapi dengan dosis 10 ton/Ha setara dengan $3 \mathrm{~kg} /$ bedeng sampai dengan 20 ton/Ha setara dengan $6 \mathrm{~kg} /$ bedeng sangat baik pada pertumbuhan dan hasil tanaman buncis. Ini dapat dilihat dalam perlakuan yang diamati, unsur K dengan menggunakan dosis $3 \mathrm{~kg} /$ bedeng dan $6 \mathrm{~kg} / \mathrm{bedeng}$ samasama menghasilkan pertumbuhan tinggi dan jumlah daun buncis yang baik dari minggu ke 2 sampai dengan minggu ke 6 , serta berpengaruh baik untuk hasil panen dibandingkan tanpa menggunakan pupuk kandang. Hal ini menunjukkan bahwa pupuk kandang sapi dengan dosis tersebut, mampu memenuhi kebutuhan tanaman buncis, hal ini sesuai dengan manfaat pupuk kandang untuk menyediakan unsur hara makro dan mikro yang bisa memperbaiki struktur tanah, sehingga pertumbuhan tanaman bisa optimal. (Lingga, 2008 dalam LJ., Buton, 2013).

Pemberian pupuk $\mathrm{N}$ berpengaruh nyata terhadap pertumbuhan dan hasil tanaman buncis. Hal ini disebabkan karena unsur hara yang terkandung dalam unsur $\mathrm{N}$ yang diberikan dapat lansung diserap oleh tanaman dan dapat mencukupi untuk menunjang pertambahan pertumbuhan tanaman buncis. Didalam perlakuan yang diamati, unsur N dengan menggunakan dosis pupuk $200 \mathrm{~kg} / \mathrm{Ha}$ setara dengan $0,06 \mathrm{~kg} /$ bedeng dan $400 \mathrm{~kg} / \mathrm{Ha}$ setara dengan $0,12 \mathrm{~kg} /$ bedeng sama-sama menghasilkan peningkatan pada tinggi tanaman dan jumlah daun, sehingga dapat mempengaruhi jumlah polong, panjang polong dan berat polong.

Interaksi pemberian pupuk kandan sapi dengan pupuk urea $(\mathrm{N})$ sangat berpengaruh nyata terhadap pertumbuhan dan hasil tanaman buncis. Hal ini disebabkan karena unsur dari kedua pupuk saling melengkapi dalam kebutuhan tanaman buncis, sehingga ketika dikombinasikan dapat berpengaru nyata terhadap pertumbuhan dan hasil tanaman buncis. Hal ini dapat dilihat dalam perlakuan yanag diamati dalam tabel hasil penelitian dari minggu ke 2 sampai minggu ke 6 yang menunjukan peningkatan yang sanagat nyata bila dibanding dengan perlakuan lainnya.

\section{PENUTUP}

Berdasarkan hasil dan pembahasan, maka dapat disimpulkan bahwa pemberian pupuk kandang sapi (organik) 10 ton/Ha setara dengan $3 \mathrm{~kg} /$ bedeng dan 20 ton/Ha setara dengan 6 $\mathrm{kg} /$ bedeng memberikan pengaruh nyata terhadap pertumbuhan dan hasil tanaman buncis dan pupuk Urea (anorganik) $200 \mathrm{~kg} / \mathrm{Ha}$ setara dengan 0,06 kg/bedeng dan $400 \mathrm{~kg} / \mathrm{Ha}$ setara 
dengan 0,12 $\mathrm{kg} /$ bedeng memberikan pengaruh nyata terhadap pertumbuhan dan hasil tanaman buncis. Interaksi antara pemberian pupuk kandang sapi (organik) 10 ton/Ha setara dengan $3 \mathrm{~kg} /$ bedeng dan pupuk Urea (anorganik) $200 \mathrm{~kg} / \mathrm{Ha}$ setara dengan 0,06 kg/bedeng memberikan pengaruh yang sangat nyata terhadap pertumbuhan dan hasil tanaman buncis.

Saran kebiasaan penggunaan pupuk kimia untuk meningkatkan hasil budidaya, bisa dikurangi karena penelitian ini telah membuktikan bahwa penggunaan pupuk organik kandang sapi jika dikombinasikan dengan pupuk urea $(\mathrm{N})$ dapat berpengaruh baik terhadap pertumbuhan dan hasil tanaman buncis, serta tetap menjaga kestabilan unsur hara tanah sehingga bisa digunakan dalam jangka waktu lama serta diharapkan dapat dilakukan penelitian lanjut untuk mengetahui unsur-unsur lain yang belum diteliti sehingga nantinya dapat mengungkap temuan baru yang dapat memberikan manfaat yang positif untuk pertanian di Indonesia khususnya pertanian di Pulau Buru.

\section{DAFTAR PUSTAKA}

Aryawijaya, 2008. Pengaturan jarak tanam untuk meningkatkan produksi tanaman kacang-kacangan dan umbi-umbian. Skripsi universitas brawijaya. Malang.

BPS. 2005 , 2009, 2014. Badan pusat statistik Kabupaten Buru. Namlea.

Buton. LJ. 2013. Pengaruh pemberian pupuk bioboost dan jarak tanam terhadap pertumbuhan dan produksi tanaman kacang buncis.Skripsi Universitas Iqra Buru. Namlea.

Djoehana, S. 1986. Pupuk dan Pemupukan. Penerbit CV Simplex, Jakarta.

Hanafia A. 2009. Rancangan percobaan teori dan aplikasinya. Penerbit PT. Raja Grafindo Persada, Jakarta.

http://id.wikipedia.org/wiki/Kacang_buncis.

http://www.petrokimia-gresik.com/urea.asp diakses pada tanggal 16 0ktober2016.

http//www.situshijau.co.id./ Organic Vegetabie Cultivation in Malaysia diaksespada tanggal 28 Oktober 2016.

Kertapraja dan Djuriah, 1992. Budyidaya Tanaman Buncis . Pertanian Bandung.

Kominfo-Newsroom - Departemen Pertanian, 2009).

Lestari AP.. 2013. Pengembangan Pertanian Berkelanjutan melalui Subtitusi Pupuk Anorganik dengan Pupuk Organik. Jurnal agronomi Universitas Hasanuddin. Makassar.

Peter Tandisau dan Herniawati.2012. Balai Pengkajian Teknologi Pertanian (BPTP). Sulawesi Selatan Suwarman S.W. 2005. Bertanam buncis. PT Musi Perkasa Utama. Jakarta.

WWW.Dinas pertanian profinsi Maluku.COM. 